Thomas A. Baldwin, Monterey Oil Co., Los Angeles

Productive Possibilities of Butano Sandstone, Santa Cruz County, California

The Butano sandstone formation has been penetrated by ro modern wells. This principal prospect zone of the Santa Cruz mountain area is a generally impermeable body. More permeable parts of the formation have been located near its top, interbedded with basal parts of the San Lorenzo shale.

Stratigraphic and depositional conditions in which the Butano may be a permeable prospect are still present.

William Z. Elmore and Benjamin C. Lupton, General Petroleum Corp., Los Angeles

Northwest Extension of West Cat Canyon Oil Field, Santa Barbara County, California

The West Cat Canyon oil field is in the Santa Maria basin, approximately ro miles southeast of the town of Santa Maria. Production is from Sisquoc (Pliocene) sands, discovered in I 908 , and from fractured shales and cherts in the Monterey formation (upper Miocene), discovererl in 1938 .

The field has a cumulative production (January I, I 952 ) of $52,000,000$ barrels of oil from 2,900 acres. Of this production, 22,000,000 barrels is from the Pliocene and $30,000,000$ barrels from the Miocene.

The Miocene section in the field is similar, in part, to that of the Santa Maria Valley field, the main differences being in the thickness and age of the chert.

The productive limit of the field has been extended northwest by the progressive drilling of stepout wells. The accumulation in the extended area is mainly due to faults which interrupt the northwest plunge of the structure, and to fracturing and resultant permeability ahove the main producing zone.

Ira H. Cram, Continental Oil Co., Houston, Texas

Lessons of a Decade

The performance of the petroleum industry during the post-Pearl Harbor decade was outstanding. Lessons of importance regarding the art of discovery and the future of discovery were taught. The more important are reviewed. Analysis of the results indicates that the nation is not running out of resources and the industry is not running out of resourcefulness. The industry, therefore, faces the future with confidence in its ability to find adequate supplies of hydrocarbons. The author is confident that the industry will find such supplies if it recognizes and successfully copes with certain adverse forces. These are discussed in some detail.

Herbert B. Hagen, Humble Oil \& Refining Co., Houston, Texas

Continuous Profiling Type Dipmeter

The general principles of determining, from a bore-hole, the dip and strike of subsurface formations by a continuous profiling method are discussed. The profiling type dipmeter is based on the principle that the softer formations erode to a greater extent than the hard formations during the drilling process. A part of a dipmeter-survey record is shown to illustrate the computation of dip by measurements taken directly from the log. The device, which makes a continuous measurement of the logging tool's orientation with respect to compass North as well as the amount and direction of the bore-hole inclination, is demonstrated. A true dip computer is discussed briefly.

Results of dipmeter surveys on drilling wells are illustrated and discussed. The results obtained with the profiling type dipmeter have been proved valuable in the study of subsurface conditions.

Milton C. Born, Amerada Petroleum Corp., Los Angeles

Geophysical Comparisons at Dinuba, Tulare County, California

A structural anomaly near Dinuba, California, is inferred from four different geophysical surveys and a core hole program. The similarity in contoured results of the applied methods is unique in exploration history. Some idiosyncrasies in comparing geophysical maps are briefly discussed.

\title{
S.E.P.M. ABSTRACTS
}

Jonn F. MANN, JR., Lniversity of Southern California, Los Angeles

Influence of Submarine Canyons on Intrusion of Ocean Water into Fresh-Water Aquifer

Detailed hydrologic studies along the California, coast reveal that important fresh-water aquifers are exposed in submarine canyons or, if not exposed, are in hydraulic continuity with the ocean in the canyons. In the typical aquifer, which has a low-angle seaward dip, the effect of submarine canyons is to produce submarine outcrops abnormally close to shore. Under natural conditions, especially during wet cycles, the piezometric surface had a strong seaward slope and fresh water escaped at the submarine outcrops, especially those in the submarine canyons. The volume of stored fresh water in the submarine extensions of the aquifer is reduced by an amount proportional to the volume of the 
aquifer lemoved during the formation of the canyon. Accompanying excessive pumping of the aquifer will be the development of a landward slope of the piezometric surface and the intrusion of ocean water into the submarine area of the aquifer. The first water wells abandoned because of ocean water will most likely be in the vicinity of the submarine canyons.

TAkeo Susuki, University of California at Los Angeles

Faunal Assemblages from Type Topanga Formation, Santa Monica Mountains, California

The middle Miocene Topanga formation at its type locality in Topanga Canyon, ro miles northwest of Santa Monica, Los Angeles County, California, consists of more than 8,000 feet of conglomerates, sandstones, and shales with intercalated basalts. An abundant molluscan fauna, obtained from four different horizons within the formation is divisible into two major faunal assemblages separated stratigraphically by 1,200 feet of barren beds. The lower assemblage ranges through approximately 200 feet of strata at the base of the formation and is characterized by the presence of Turritella ocoyana s. s. and Pecten (Lyropecten) crassicardo n. var. The upper assemblage ranges through the three upper horizons and is characterized by the presence of numerous specimens of Turritella ocoyana topangaensis and Turritella temblorensis.

Thomas Clements, University of Southern California, Los Angeles

Further Evidence of Wind-Blown Rocks on Playas

Since the report by McAllister and Agnew in r 948 of trails left by rocks on the Racetrack Playa, there has been much speculation as to their origin. Those authors attributed the movement of the rocks to the wind. However, since the Racetrack is at a high elevation, where freezing occurs during the winter, the aid of ice could not be ruled out. The finding of similar trails on Little Bonnie Claire Playa, recently reported by the present writer did not completely eliminate ice as a possible aid since it, too, is at a relatively high elevation.

The same phenomenon has since been observed on a playa at 1,60o feet elevation, and somewhat farther south than either of the previously mentioned ones. The aid of ice seems to be definitely ruled out, as well as possible pushing about by human beings. This leaves the wind as the most likely agent causing the movement of the rocks, as first suggested by McAllister and Agnew.

Fred B. Phleger, Frances L. Parker, and Jean F. Peirson, Scripps Institution of Oceanography, La Jolla

North Atlantic Core Foraminifera Collected by Swedish Deep-Sea Expedition

Foraminifera have been studied from 39 long deep-sea cores and from 53 undisturbed surface sediment samples collected from the North Atlantic. Mid-latitude and low-latitude planktonic assemblages can be differentiated, with at least five different distribution types. The long cores contain faunas normal for their latitude alternating with faunas typical of higher latitudes. These are suggested as representing alternating cold and warm epochs, mostly Pleistocene; correlation of these epochs appears possible in a mid-latitude series of cores.

Several cores contain shallow-water Foraminifera which have been displaced from shallow water. It is suggested that much of the mud in the deep ocean may be the finer fraction of sediments displaced from shallow water. Four cores contain planktonic Foraminifera of Miocene age. There is abundant evidence of solution of calcium carbonate; it is suggested that most of this solution occurred at the sediment surface and is related to the rate of production of Foraminifera.

A mixed high and low latitude plank tonic fauna occurring off Africa between $15^{\circ}$ and $20^{\circ} \mathrm{N}$. Lat. is attributed to mixing at the convergence of the Equatorial Counter Current and the Canaries Current. Mixed planktonic faunas occur in lower sections of cores off Africa between $0^{\circ}$ and $7^{\circ} \mathrm{N}$. Lat.; this suggests that the convergence area was displaced southward during the past.

\section{W. Dwight Pierce, Los Angeles County Museum, Los Angeles}

Significance of Insect Remains in Asphalt Deposits

Asphalt deposits at Rancho La Brea, Carpinteria, McKittrick and Sulphur Mountain have been studied for insect remains. An astonishing number of species has been found varying in size from about I millimeter to 3 inches.

The four deposits studied present three distinct types: Rancho La Brea and Carpinteria were open pools due to upward surge of asphalt, with consequently constant movement in the liquid aspha]t. The McKittrick field was due to chimneys opening on hillsides and the slow flow of the asphalt down the slopes caught many insects and small animals, with the larger animals only caught in the pools formed at the bottom. Sulphur Mountain is an almost vertical flow down a mountain side with small pools caught on ledges. Here as in McKittrick the insects are deposited where they die.

The stratification of the McKittrick field will permit climatic correlations and also studies in the gradual change of insect characters over a long period of time.

The finding of certain carrion insects indicates the time required for complete submersion of the animal. This took up to three months at La Brea, but two to three years at McKittrick. 